\title{
The Conceptual Framework of SMEs Financial Success in Sultanate of Oman
}

\author{
Basat Hilal ${ }^{1}$, Noor Fareen Abdul Rahim² and Mohammad Iranmanesh ${ }^{3}$ \\ ${ }^{1}$ Faculty of International Business Administration, Nizwa College of Applied Sciences, 699, Nizwa, Sultanate of Oman \\ ${ }^{2}$ Graduate School of Business, Universiti Sains Malaysia, 11800, Penang, Malaysia \\ ${ }^{3}$ Faculty of Business and Law, Edith Cowan University, 270, Joondalup Drive, Australia
}

ABSTRACT - SMEs financial success contributes to the nation's GDP and helps in jobs creation, while SMEs financial failure will lead to issues, such as low job creation and Non-Performing Loans. From the perspective of the Sultanate of Oman, the SMEs financial performance is one of the government major concerns due to its significance and implications on the future of the national economy. Thus, it is worthwhile to assess the SMEs financial literacy and entrepreneurs' competencies (EC) as enablers of SMEs financial performance betterment. However, review of the literature and the practical evidence available give the impression that each sub-dimensions of entrepreneur competencies $(E C)$ does not effect identically on SMEs financial performance. Therefore, it has become important to understand the financial literacy and entrepreneur competencies (EC) sub-dimensions effect on SMEs financial performance so that their significance and importance can be identified. This study aims to provide empirical evidence about the effect of financial literacy and each sub-dimensions of entrepreneur competencies (EC) on SMEs financial performance in the Sultanate of Oman. Besides, this research tends to examine the role of firm resources availability and government support as moderators. Resource-Based View Theory (RBV) will be adopted to extend the existing literature on SMEs financial performance determinants from SMEs entrepreneurial perspective. As research novelty and theoretical contribution, this research study's the interactions of financial literacy and each sub-dimensions of entrepreneur competencies $(E C)$ with firm resources availability and government support, as moderators. The convenience sampling method will be used with SMEs sample size of 200 and 300 questionnaires will be distributed to SMEs founders/owners in Sultanate of Oman. The structural equation modelling (SEM) through partial least square (PLS) approach will be used to test the study hypotheses. The present research findings are expected to broader the picture of entrepreneur competencies $(E C)$ and SMEs performance researches by revealing the financial literacy and each sub-dimensions of entrepreneur competencies $(E C)$ effect on SMEs financial performance. Further, it may confirm the moderating role of firm resources availability and government support on SMEs financial performance.
ARTICLE HISTORY

Received: $30-05-2020$

Accepted: 24-07-2020

KEYWORDS

Small Medium Enterprises

(SMEs), Entrepreneur Competencies (EC), Financial

Literacy, Resource-Based

View Theory (RBV),

Omanization

\section{INTRODUCTION}

Despite being relatively small in size and made up of highly fragmented and heterogeneous industries, small and medium enterprises SMEs are characterised as the 'engines of growth' by economists (The Economist, 2010; OECD, 2010; Ng, 2016). SMEs account for significant contributions to GDP growth, new job creation, and poverty reduction. According to Mandl, Hurley, Ledermaier and Napierala (2016), SMEs are an essential contributor in jobs creation and solving unemployment crises. However, previous studies been conducted on SMEs financial performance showed high rates of SMEs failures. In the international context, the SMEs share a high rate of failure as 20 per cent of SMEs would be eliminated within the first year of activity (Franco \& Haase, 2010; Bae, Qian, Miao, \& Fiet, 2014). Furthermore, Driessen and Zwart 2007 and Al-Damen (2015) endorsed that 50 per cent of businesses would vanish during their first five years of foundation. Whereas, in developing countries, SMEs has more constrains to become financially successful. For example, the SMEs financial performance in Africa reflects a high rate of SMEs mortality, and it is posited that five out of seven new SMEs fail (Adcorp, 2012; Francis and Willard, 2016). At the same time, SMEs in the Middle East are not excluded from high failure rates. According to Barazandeh, Parvizian, Alizadeh and Khosravi, (2015), in Iran's it is revealed that only 10 per cent of SMEs business achieved financial success.

Small and Medium-sized Enterprises (SMEs) are recognised as the backbone of any economy (Fong, Ocampo, Alarcón 2011; Bahaddad, Al Ghamdi \& Houghton, 2012; Rahbi, 2017). They play an essential role in job creation as well as ensuring a country's economic stability. The SME sector is viewed as an essential component of modern industrialised societies. Therefore, it is crucial to study the determinants of SMEs financial performance. 
SMEs financial performance has several determinants, including entrepreneur competencies (EC) and financial literacy. Man et al. (2001) revealed that entrepreneur competencies (EC) positively impact SMEs business performance through his novel model of SME competitiveness. In the year 2008, Men et al. (2008) have introduced the entrepreneur competencies (EC) with eight sub dimensional competencies (i.e. strategic competencies, opportunity competencies, operation competencies, commitment competencies, relationship competencies, analytical competencies, technical competencies and innovation competencies). Henceforward, there is a growing body of literature attesting that the success or failure of SMEs business is dependent on entrepreneur competencies (EC). Mitchelmore and Rowley (2013) conducted a study in England and Wales targeted women entrepreneurs and revealed that strong entrepreneur competencies (EC) positively impact SMEs business performance. Besides, Tanoira and Valencia (2014) in Mexico, have found a positive impact of entrepreneurial competencies (EC) on SMEs business performance Besides, Ahmed et al. (2017) study on entrepreneur competencies (EC) has confirmed its positive effect on SMEs business success. Several studies provided empirical evidence on the positive impacts of entrepreneur competencies (EC) on SMEs business performance in developing countries (Nasuredin, Halipah, \& Shamsuddin, 2016; Tehseen, 2017).

In contrast, these researches have overlooked the sub dimensional effect of entrepreneur competencies (EC) on SMEs business success. Therefore, there is a need to validate that sub dimensional competencies of entrepreneur competencies (EC) effect on SMEs business performance. However, the present research adopts financial performance dimension and excludes the non-financial dimension to capture SMEs business performance.

The sub dimensional competencies of entrepreneur competencies (EC) effect on BoP business performance has been studied by Rahman et al. (2016). However, the context of the research was Bottom of Pyramids (BoP), business in Bangladesh. Further, the research has adopted the capability theory for measuring the wellbeing as an outcome of BoP business performance. However, the research showed that only opportunity competencies, commitment competencies and innovation competencies have a positive and significant relationship with BoP financial performance and the strategic competencies, relationship competencies, analytical competencies and technical competencies have the least relationship with entrepreneurial BoP financial performance. Thus, there is a need to strengthen the relationship of these sub dimensional competencies of entrepreneur competencies (EC) with businesses financial performance in SMEs context.

Further, Eniola and Entebang, (2017), Bongomin, Ntayi, Munene and Malinga, (2017) concluded that financial literacy among SMEs owners and managers is critical for SMEs financial performance. Drexler, Fischer, and Schoar (2014) also concluded that financial literacy improves firms' financial practices, objective reporting quality and sales revenue which improves the SMEs financial performance. Accordingly, inadequate financial literacy may be a barrier to improved SMEs financial performance. In another study done by Zaridis and Mousiolis (2014), stated that lack of appropriate management competence, including financial literacy, is the primary cause SMEs poor financial performance. Furthermore, Ropega (2011) and Griffin (2012) confirmed that most financial failures are caused by the entrepreneurs of SMEs that are incompetent with lack of experience in managing the business and taking instant remedial action in a crisis. Therefore, Bird (2019) has explored the origins of entrepreneurs' competencies (EC) and suggested for government and other educational entities to come up with educational programs which assist in embedding the appropriate competencies and financial literacy among entrepreneurs to improve SMEs financial performance.

Sultanate of Oman's economy is considered to be one of the developing Middle East economies. SMEs in Oman are defined based on the number of employees and sales turnover. According to the Public Authority for Small and Medium Enterprises of Oman, SMEs are any establishment which has less than 100 workers and the sales turnover less than OMR 3 million. Also, SMEs in Oman are divided into three categories, as explained in the following table:

Table 1.

\begin{tabular}{lcc}
\hline & Small Enterprises & Meduiem Enterprises \\
\hline $\begin{array}{l}\text { Number of Workers } \\
\text { Annual Revenue }\end{array}$ & $(6-25)$ & $(26-99)$ \\
OMR 100K-500K & OMR 500K $-1 \mathrm{M}$ \\
\hline
\end{tabular}

Source: Public Authority for SMEs Development (2019)

SMEs Development Symposium, conducted in 2013, found that one of the SMEs weaknesses is the lack of capital and access to finance in addition to the entrepreneurs' inadequate competencies. Accordingly, Oman's government has decided to provide financial and non-financial support to SMEs. With government financial support, it became easier for SMEs to obtain credit assist. Whereas, government non-financial support is associated with the enhancement of 
entrepreneurs' knowledge and development of entrepreneurial skills via seminars and training workshops. Yet, SMEs in Oman have not achieved the desired trajectory of success due to SMEs financial performance. Though the number of SME business units also showed an increase in recent years. Engineer Naif Al Balushi, Head of SMEs development and support in Riyada has revealed: "Oman has 42,163 SMEs including small and medium businesses distributed among all eleven governorates of Oman". (SMEs businesses' growth, 2019). However, According to the SME Development Fund of Oman's SMEs, contributes up to $14 \%$ in Oman's GDP. Besides, according to CEIC data, the NPL in Oman was only $2.2 \%$ in January 2017 while it has increased dramatically to reach 3.2\% by July 2019 (Oman Non-Performing Loans Ratio, 2019). This indicates that the Central Bank of Oman observed overall non-performing loans increase by $50 \%$ in July 2019 compared to July 2017. This NPL is partially attributed to SMEs failure in loan repayment as a consequence of SMEs financial failure, besides retail and corporate NPL.

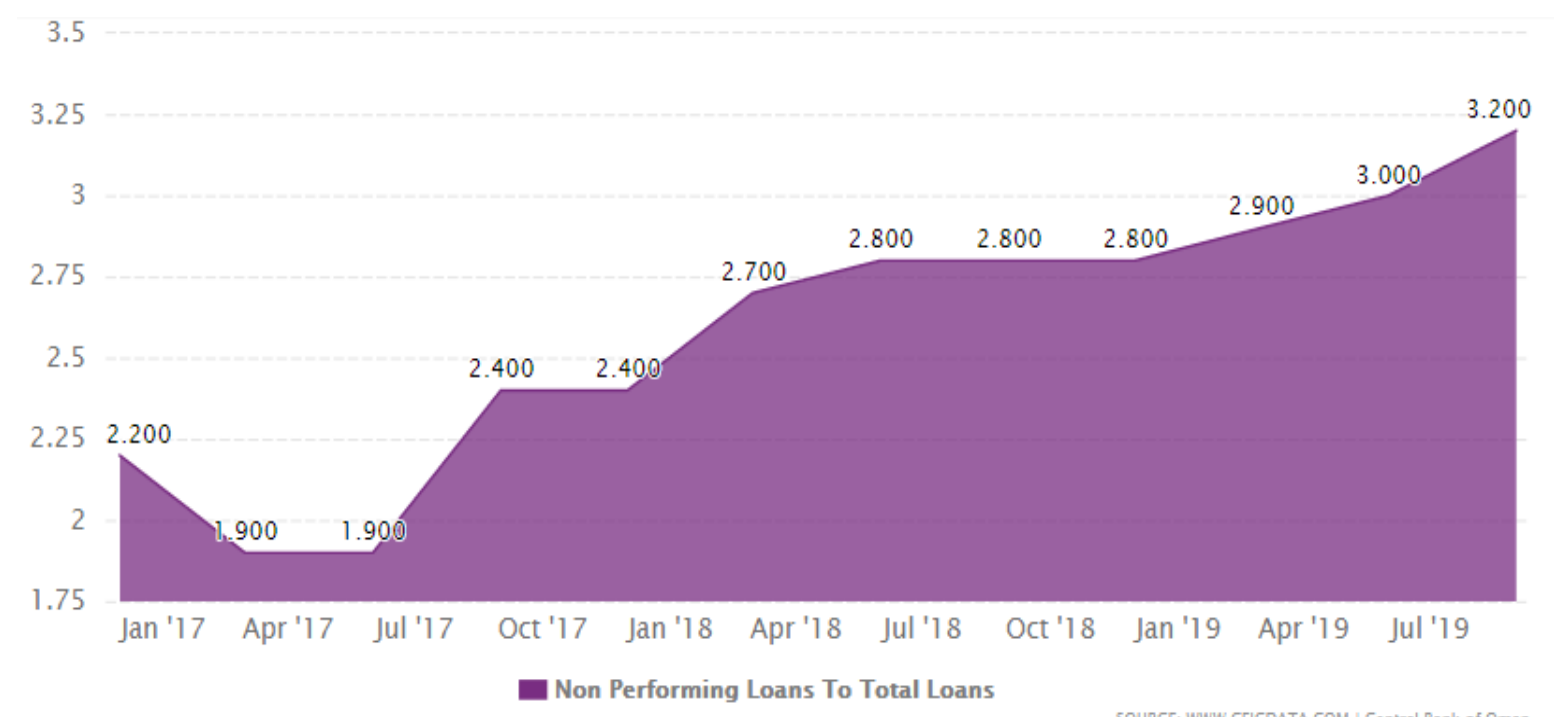

Figure 1. Oman's Non-Performing Loans. (Source: CEIC Data, 2019)

As SMEs are known to be significant contributors to employment generation, economic empowerment and social wellbeing of the majority of the citizens in developing economies. The SMEs financial success could enhance the employment of Omani citizens and absorb them more into the job market. Besides, SMEs financial success mitigates non-performing loans cases for government and non-government credit providers which represent crucial issue on the national economy. Thus, Oman's government has a significant role in cultivating the SMEs to get the advantage of SMEs contribution to the nation's economic growth. Further, to mitigate cases of SMEs failure. Given this, the SMEs financial performance is paramount interest for entrepreneurs as well as the government. Thus, the government of Oman devotes special attention to SMEs that is highly reflected in Oman's preliminary Vision 2040. Oman Vision 2040 has been introduced in January 2019, and it documents outlines plans to support Oman's SMEs.

The previous researchers did not consider to include the financial literacy while studying the entrepreneur competencies (EC) effect on SMEs performance under SMEs competitive model developed by (Man et al., 2001). This is understandable, as the technical competencies and analytical competencies are expected to cover different areas of SMEs business operations, including financial operations. The proposed financial literacy variable in present research devotes more attention to generating the financial statements and performing financial ratio analysis periodically. However, most SMEs in Oman are not engaged in financial statement generation and performing financial ratio analysis. It is attributed to one main reason, the generation of audited financial statement for SMEs is not obligatory by the government except for SMEs who avail credit facilities exceeding OMR 250,000/-. Thus, audited or in house financial statement generation is a voluntary act for most SMEs in Oman, which ultimately may stimulate the financial literacy levels. As a result, financial statement generation is detached from technical competencies because it is voluntary and not been carried out regularly by most SMEs in Oman. Consequently, the financial ratio analysis is overlooked and commonly not performed; this may justify the purpose of separating the finical literacy from analytical competencies. Therefore, the present research is intended to study the effect of financial literacy on SMEs financial performance.

Further, previous researches have defined entrepreneur competencies (EC) by different dimensions (i.e. six, or, eight, or ten) For example, Brinckmann, (2006) and Ahmed et al. (2018) have taken up six entrepreneur competencies. Also, Ahmed et al. (2009) have taken up eight entrepreneur competencies. In comparison, Mitchelmore and Rowley (2013) have applied five entrepreneur competencies. In most of the SMEs and entrepreneurship researches, SMEs business success has been defined by altered dimensions (i.e. one, two, or three) financial performance, non-financial performance and sustainability (Ahmad et al., 2009). In the hierarchical model or higher-order constructs have been defined as constructs involving more than one dimension, and these dimensions capture some proportion of overall reflective latent 
variables. (Becker et al., 2012). While applying the hierarchical model it is necessary to consider that indicators and the constructs could be either reflective or formative, henceforth, four different combinations have been categorised so far (Jarvis et al., 2003; Ringle et al., 2012).

These four different combinations are 1) reflective-reflective, type I model; 2) reflective-formative, type II; 3) formative-reflective, type III; and 4) formative-formative, type IV. Accordingly, Rahman et al. (2016) revealed that entrepreneur competencies (EC) and business success had been considered as reflective - reflective, type I. Due to the reflective nature of entrepreneur competencies (EC) and SMEs business performance latent variables and to provide a broader picture for entrepreneur competencies (EC) and SMEs business performance researches area, the present research adopts seven sub-dimensions of entrepreneurs competencies (EC) that are: (strategic competencies, opportunity competencies, commitment competencies, relationship competencies, analytical competencies, technical competencies and innovation competencies). Besides, based on the present research context and scope, SMEs financial performance dimension has been adopted, and other SMEs business performance dimensions are excluded. To intensify, adding or dropping any of the dimensions/items will not change the conceptual meaning of the latent variables specifically in the reflective-reflective model (Coltman, Devinney, Midgley, \& Venaik,2008).

Though, there are several external factors influence on SMEs financial performance that has been studied as moderating variables; i.e. SMEs relationship with buyers and suppliers, perceived business environment and environmental turbulence (Ahmed 2007; Ahmed, Ramayah, Wilson \& Kummerow 2010; Tehseen \& Ramayah 2015). For the moderating role of government support Shamsuddin, Sarkawi, Jaafar, and Abdul Rahim, (2017) have defined government support as the government involvement to provide SMEs with financial, non-financial support and other services. As Jacob, Johan, Schweizer and Zhan (2016) declared that SMEs, which suddenly evade financial support from the government, encounter considerable fiscal budget problems. Besides, the government must provide non-financial support through seminars and training workshops for SMEs entrepreneurs' to mitigate the consequences of inadequate entrepreneur competencies (EC) and financial literacy.

Bahari et al. (2017) has studied the moderating role of government support on the relationship of entrepreneur orientation (EO) and SMEs business success in Malaysian context and has confirmed the moderating role of government support. Further, Shamsuddin et al. (2017) confirmed that financial support, non-financial support and other business support from the government is positively related to SMEs business performance. Thus, governments in developing countries have a prominent role in improving SMEs financial performance by providing financial and non-financial support. For instance, the government provides financial support for SMEs in the form of credit facilities and other working capital facilities. Non-financial support is associated with training and workshops to enhance entrepreneurs' knowledge and fortify their skills. Therefore, to strengthen the relationship of entrepreneur competencies (EC) subdimensions with SMEs financial performance, the present research deploys government support as a moderating variable.

Chandler and Hanks (1994) identified the firm resources as founder or owner abilities to gather resources and use them, as well as the overall availability of resources; which are essential inputs into the production process including items of capital equipment, skills of individual employees, finance, and so on According to RBV theory these internal firm resources are endowment for competitive advantage resulting in business success (Barney, 1991). Therefore, as an important implication for scholars of (EC) is the need to consider the contingent role of resources internal to the SME`s. Hofer and Schendel (1978) sated that financial resources, physical resources, human resources, firm resources, and technological resources helped firms to achieve their goals. Further, previous researches (Edelman, Brush \& Manolova, 2002; Lau, 2011; Albrecht, Breidahl \& Marty, 2018) has studied the role of firm resources in different contexts and confirmed that organisational resources have a positive relationship with firms performance and its sustainability. Besides, Leonidou Palihawadana and Theodosiou (2011) has adopted the firm resources, as a mediator, to study its effect on strategy, competitive advantage, and firm performance in the context of the export industry. The current research considers SME`s firm resources that comprise of human resources, capital resources, monetary resources and raw materials that would enable in the endowment of competitive advantage, which drives SME`s financial success. Due to constrain faced by SMEs in Oman related to the financial resources, physical resources, human resources and technological resources, the present research aim to strengthen the relationship of entrepreneur competencies (EC) subdimensions with SMEs financial performance by proposing the moderating role of firm resource availability.

Deliberating to Mitchelmore and Rowely (2010) and Ahmed et al. (2018) studies of entrepreneur competencies (EC) and their association with SMEs business performance, it is noteworthy that there are still considerable gaps in the literature. Besides, to the inconsistencies in previous researches raised by (Rahman et al. 2015; Nasuredin et al., 2016) that revealed different results about the relevance of entrepreneur competencies (EC) sub-dimensions to SMEs business success. Therefore, in an attempt to fill up these gaps and to expand the theoretical knowledge the present research study the interactions of incorporated moderators; firm resources availability and government support on financial literacy and entrepreneur competencies (EC) sub-dimensions relation with SMEs financial performance. As all these variables are at the organisational level, therefore, the present research adopts RBV theory. There are several scholars also adopted RBV theory in their studies on entrepreneur competencies (EC) relationship with SMEs business success (e.g. Tehseen \& Ramayah, 2015; Nasir et al., 2017; Ahmed et al., 2017, Al Mamun et al., 2019). According to RBV, the four criteria for 
sustainable advantages of resources are valuable, rare, inimitable, and non-substitutability (Barney, 1991). Resources can be both tangible and intangible (Werner felt, 1984). RBV considers intangible resources as human capital characteristics such as competencies (Barney et al., 2001). Traits, capabilities, and skills can be translated into a unique internal set of resources that small firms must rely on (Lerner \& Almor, 2002). Further, it is noteworthy to mention the importance of SMEs firm resources, according to RBV theory, to obtain a competitive advantage, as the driver of SMEs business success. (Barney, 1991). Previous researches (Edelman, Brush, \& Manolova, 2002; Lau, 2011; Albrecht, Breidahl, \&Marty, 2018) has studied the role of firm resources in different contexts and confirmed that firm resources have a positive relationship with firms performance and its sustainability. Entrepreneur competencies (EC) are difficult to be imitated by rivals because of the ambiguity in its origin and embeddedness. Entrepreneur competencies (EC) and financial literacy are unique management skills that can be considered as resources for accomplishing excellent enterprise financial performance. In Summary, the present study contributes to the theoretical body of knowledge on entrepreneur competencies (EC) and financial literacy with SMEs financial performance.

The findings of the study will help Oman's government to identify the best mechanism to nurture the SMEs and to meet the economic diversification goals besides the acceleration of job creation in the SMEs sector. Besides, these research findings may serve the policymakers as input for Oman vision 2040 practically in SMEs development fragment, the findings of the present research may be used by Oman's government for the coming five years strategic plan. Also, the research contributes toward the Omani community through the promotion of improving SMEs financial performance that grants the fair wealth distribution and social wellbeing. Further, the research findings contribute toward government and non-government SMEs credit providers as SMEs credit providers are solely relying on financial analysis and financial projections to assess the SMEs financial performance. Whereas, in absences the required financial reports, it is worthwhile to consider the entrepreneurs' competencies' (EC) and financial literacy as determinants of SMEs financial performance that may also mitigate SMEs Non Performing Loans. Besides, the present research findings provide an insight for SMEs on most significant entrepreneur competencies sub-dimensions which ultimately help them to uplift their SMEs financial performance. Further, through the creation of knowledge related to the entrepreneur competencies (EC) and SMEs financial performance in Oman, the present research serves the Omani citizens, who are planning to have entrepreneurship endeavour to flourish and establish their own SMEs in future.

To the best of the researcher's knowledge, no previous study has been done looking on the moderating effect of firm resources availability and government support on the relationship between entrepreneur competencies (EC) subdimensions and financial literacy with SMEs financial performance in Oman from Resource-Based View Theory (RBV) perspective. Therefore, this research tends to study the relationship of financial literacy, entrepreneur competencies (EC) sub-dimensions (strategic competencies, opportunity competencies, commitment competencies, relationship competencies, analytical competencies, technical competencies and innovative competencies) relationship with SMEs financial performance. Further, it examines the moderating role of firm resources availability and government support on SMEs financial performances

\section{LITERATURE REVIEW AND HYPOTHESES DEVELOPMENT}

\section{SMEs Financial Success}

Ahmed, Wilson and Kummerow (2011) had defined SMEs financial success as SMEs ability to generate income and profits and demonstrate some levels of growth which are indicated by business sales and income. Besides, Brüderl and Preisendörfer (1998) have defined the SMEs financial success asserted on traditional financial measures of performance, such as profitability, return on investment, and sales turnover to predict the success or failure of a firm. While attaining SMEs financial success, it is vital to generate income and profits and demonstrate some levels of growth which are indicated by SMEs sales and income (Perren, 2000). SMEs entrepreneurs' ultimate goal is to make a profit and ensure their business success. SMEs are known to be significant contributors to employment generation, economic empowerment and social wellbeing of the majority of the citizens in developing economies. Given this, SMEs business success is paramount interest for entrepreneurs and government as several kinds of research have been conducted on SMEs business success, from entrepreneurial competencies (EC) prospective by other researchers ( Man et al. , 2002; Ahmed 2007, Man et al. 2008, Ahmed et al. 2010; Tehseen et al. 2015; Rahman et al. 2016; Al Mamun et al. 2018). Accordingly, entrepreneurs' competencies (EC) are characterised as organisational capabilities that enable SMEs business success. Likewise, in previous researches scholars endorsed that entrepreneurial and SMEs training would have positive effects on SMEs performance in developing economic context ( Ekpe, Mat \& Razak 2010; Gray, Gash, Reyees \&Crookson 2011; Karlan \& Valdivia 2011; Agbeko, Blok, Omta \& Velde, 2017).

Whereas, SMEs success has prerequisites and also different determinants like financial literacy and entrepreneurial competencies (EC). Man, Lau and Chan, (2002) has initiated the SMEs competitiveness model with a focus on entrepreneurs' competencies (EC). Further, Men, Lau \& Snape, (2008) has conducted a study on SMEs competitiveness model with a focus on entrepreneurs' competencies. Besides, Ahmed, Halim and Zainal, (2010) have proposed and confirmed direct relation between the entrepreneurial competencies (EC) and SMEs success in developing nations. However, business success has been captured by different aspects and revealed from inconsistencies in previous 
researches on SMEs performance. As several types of research been conducted on SMEs financial success, besides the SMEs non-financial success, from entrepreneurial competencies prospective (Man et al., 2002; Ahmed 2007 ; Man et al. 2008; Ahmed et al. 2010, Tehseen et al. 2015, Rahman et al. 2016 Al Mamun et al. 2018). Some researchers focused on the use of financial indicators, while others considered non-financial indicators of success. (Blank, 2002; Santos \& Brito, 2012; Kodongo, 2018) has mentioned that subjective financial performance consists of three items; return on investment and sales growth to measure firms' past performance. However, the third item, i.e. market share, can't be treated as a financial indicator of performance in a strict sense, but it directly impacts the sales volumes and profitability. Accordingly, (Morgan \& Strong 2003; Ahmed et al. 2010) has suggested measurement scale for subjective financial performance consist of sale growth, return on investment and the SMEs financial performance relative to its competitors. The researchers who prefer financial measures of success usually argued that for the success of the organisations, it is vital to generate profits and to show some level of growth which is represented by the volume of their sales (Perren, 2000). Further, (Dess \&Robinson, 1984; Singh, Darwish,\& Potočnik, 2016) posit that self-reported performance measures are acceptable and are reliable as objective measures. Thus, this paper focuses on financial indicators in terms of subjective measures, of SMEs financial success in its proposed conceptual model.

\section{Resource-Based View Theory}

The resource-based view (RBV) tend to analyses and interprets resources of the firm to provide a better understanding of how firm attain a competitive advantage. According to (Barney, 1986; Hamel \& Prahalad, 1996) the (RBV) emphasises on the concept of challenging to imitate attributes of the firm as sources that initiates superiority of performance eliciting competitive advantage. Besides, Conner (1991) has stated that variances in performance among firms highly depend on its possession of unique inputs and capabilities. Further, Barney (1991) has indicated that resources which are valuable, rare, inimitable and non-substitutable provide the opportunity for the firms to achieve and maintain competitive advantages. While, the firms could utilise these resources and competitive advantages for superior performance (Werner felt, 1984; Grant, 1991; Collis \& Montgomery, 1995)

According to Barney (1991), the valuable resource enables the firm to perform and behave in ways that lead to high sales, low costs, high margins, or in others ways add financial value to the firm. Barney also emphasised that resources are valuable when they enable a firm to conceive or implement strategies that improve its efficiency and effectiveness. (RBV) helps managers of firms to understand significant of competences as the most valuable asset that requires appreciation, in addition to a superior understanding of the optimum ways to improve business performance by utilising the most critical assets. The resource-based view theory examines and explains how firm use internal resources to achieve business success. This theory emphasises the concept of difficult-to-imitate characteristics of the firm as sources of excellent performance (Barney, 1986; Hamel \& Prahalad, 1996; Madhani, 2009; Abdul Rahim, 2016). Therefore, entrepreneur competencies (EC) are considered as SMEs valuable resources (Darcy, Hill, McCabe \& McGovern, 2014) that can be used to achieve SMEs success. Besides, a high degree of financial literacy of entrepreneurs can give entrepreneurs constant access to new knowledge and information about how to manage their SMEs finances (Forbes, 2010), which in turn can allow a firm to outperform its competitors (Barney, 1991).

Furthermore, government support is imbedded into SMEs internal tangible and intangible resources. Government financial support represents an additional financial resource for SMEs. While government delivered seminars and workshops, tend to expand the SMEs managers and staff knowledge enabling them to make better decisions for SMEs financial success. The organisational resources comprise of managerial resources, production resources, and intellectual resources also play a prominent role to attain competitive advantage from RBV perspective, enabling SMEs financial and non-financial success.

From the theoretical perspective, the underpinning theory provides the foundation of a study by framing a researcher's curiosity of a situation or problem that intended to be investigated and solved. Therefore, this study contributes by testing the resource-based view theory by looking at the relationship between financial literacy and entrepreneur competencies (EC) with SMEs financial success. Besides, this study attempt to strengthen the significance of the relationship of financial literacy and entrepreneur competencies with SMEs financial success in Oman through the incorporate moderating role of firm resources availability and government support.

\section{Financial Literacy and SMEs Financial Success}

Dahmen and Rodríguez (2014) defined financial literacy as the ability to understand and use business financial statements to generate vital financial ratios to evaluate and manage a business. Further, Remund (2010) mentioned that financial literacy refers to the degree to which one understands the key financial concepts and possesses the ability and confidence to manage personal finances through appropriate, short-term decision-making, sound, long-range financial planning, while mindful of life events and changing economic conditions According to Lusardi (2013), financial literacy encompasses knowledge and cognitive skills with a set of desirable attitudes, behaviours and external enabling factors. For example, financial literacy includes increases in financial knowledge or skills and changes in financial behaviour (Hilgert, Hogarth \& Beverly, 2003; Mandell et al., 2009). Financial literacy is vital as one of the critical management competencies that contribute to SMEs financial performance, eliciting firm success and growth (Spinelli, Timmons \& 
Adams, 2011; Eniola \& Entebang, 2016). At the same time, SMEs owners' financial literacy could be considered as a significant barometer of SME financial success. Wise (2013) found that an increase in financial literacy leads to more frequent production of financial statements. Worth to mention, SMEs owners with higher financial literacy tend to produce and review more financial statements eliciting a higher probability of loan repayment and a lower probability to incur a financial loss. Drexler et al. (2014) concluded that financial literacy improves firms' financial practices, objective reporting quality and sales revenue. These deliberations emphasise that financial literacy is vital in attaining financial performance of SMEs.

Indeed, scholars have increased their efforts in examining the relationship between financial literacy with financial decision-making and its financial outcomes (Banks, O'Dea, \& Oldfield 2010; Christelis, Jappelli, \& Padula 2010; Lusardi \& Mitchell 2011; Yoong, 2011; Adomako, Danso \& Damoah, 2015 ). Moreover, Lusardi (2019) stated that individual and SME entrepreneurs with low levels of financial literacy tend to make wrong decisions by participating less in the formal financial system. Besides, Dahmen \& Rodríguez (2014) validated the positive relationship between financial literacy and SME financial performance. While, (Adomako, Danso \& Damoah, 2015; Adomako, Danso \& Ofori, 2015; Eniola \& Entebang 2017) has endorsed that financial literacy has a moderating role in SMEs success and growth. Indeed, Dzmonda and Fatoki (2019) believe that financially literate SMEs owners tend to make better financial decisions with fewer management mistakes than their counterparts who are financially illiterate. A major conclusion from most of these studies suggests a strong positive association between financial literacy and financial outcomes. e.g. (Hilgert, Hogarth, \& Beverly 2003; Banks, O'Dea, \& Oldfield 2010; Christelis, Jappelli, \& Padula 2010; Smith, McArdle, \& Willis 2010; Lusardi \& Mitchell 2011; Van Rooij, Lusardi, \&Alessie 2011; Yoong 2011; Eniola \& Entebang 2017).Financial literacy is proved to be an enabler for SMEs financial success as it helps to develop more commitment for financial reporting, analysing and incite betterment in a financial decision that mitigates the risk of financial failure. According to Dahmen and Rodríguez (2014), financial literacy is about the ability to understand and use business financial statements to generate key financial ratios to evaluate and manage a business.

Previous researches emphasised on the influence of financial literacy on SMEs business performance (Adomako \& Danso, 2014). Further, various researchers put their efforts in conducting research related to financial literacy and its relationship with financial decision making and business performance in various contexts (Hilgert, Hogarth \& Beverly 2003; Smith, Mc Ardle \& Willis 2010; Lusardi \& Mitchell 2011; Yoong, 2011). It is worthwhile that SMEs entrepreneurs need to have the financial literacy to make crucial financial decisions while executing SMEs financial operations or even facing financial challenges. Drexler, Fischer and Schoar (2014) pointed out that SME owner-managers are asked to make difficult financial decisions in many aspects of business life.

Also, it has been endorsed by Miller et al. (2009) that financial literacy is an essential tool to ensure business success. Dahmen and Rodriguez (2014) contended that those SMEs entrepreneurs who do not regularly review their financial statements nor perform financial analysis were experiencing financial difficulties which have negative consequences on SMEs financial success. The primary conclusion of most of these studies suggests a strong positive association between financial literacy and SMEs financial success. Considering Oman's SMEs context where most of SMEs are not preparing annual audited financial statements because it is not obligatory to for SMEs with credit facilities below OMR 250,000. Thus this study hypothesises that:

\section{H 1: Financial Literacy has a positive and significant relationship with SMEs financial success.}

\section{Entrepreneurial Competencies (EC) and SMEs financial Success}

Man et al. (2008) have defined the entrepreneur competencies (EC) as the total ability of the entrepreneur to perform a job and classified in eight sub-dimensions in SME`s competitiveness model (e.g. strategic competencies, operational competencies, opportunity competencies, commitment competencies, relationship competencies, analytical competencies, technical competencies and innovation competencies). Whereas, Bird (1995) defined entrepreneurial competencies as primary characteristics such as basic and specific knowledge, motives, traits, self-image, roles and skills which required for business start-up, financial survival and growth. Further, it is suggested that competencies can be seen as behavioural and observable. The role of an entrepreneur in a business venture is considered crucial, and it is studied through the competency approach. As a way of studying entrepreneurial characteristics, the competency approach has become popular to indicate the SMEs business success including the SMEs financial success (Man, Lau \& Chan 2002; Rodermund, 2004; Men, Lau \& Snape 2008; Ahmed, Halim \& Zainal 2010; Mitchelmore \& Rowley 2013; Al Mamun \& Fazal 2018; Bird, 2019). The present research deploys first-order constructs for seven competencies which are: strategic competencies, operational competencies, opportunity competencies, commitment competencies, relationship competencies, analytical competencies, technical competencies and innovation competencies). 


\section{Strategic Competencies and SMEs financial success}

Strategic competencies necessitate the entrepreneur to have a vision or a broader depiction in their mind for their business with clear goals and to formulate and implement strategies to achieve these vision and goals. According to Man, Lau and Chan (2002), the strategic competency refers to the establishment, evaluation and execution of firm strategies. Stone and Pemberton (2002) stated that strategic competencies involve strategic thinking and allow entrepreneurs to direct their actions and take decisions more strategically to get significant advantages and financial success. Besides, there is an endorsement by (Man et al., 2008; Ahmad et al., 2010) that strategic competencies can lead to successful SMEs performance in the long run. Strategic competencies also help to cope with the uncertainty of business through having a long-term vision that eventually facilitates financial performance. A study by Mohsin (2015) in Malaysia reported that strategic competencies are positively related to SMEs business success. Therefore, it is also expected that elements of strategic competencies will lead to SMEs financial success. However, Rahman et al. (2016) in his study of Bangladesh BoP firms found insignificant relation of strategic competencies with BoP business success. Thus, the study hypothesised the following:

\section{H2: Strategic competencies have a positive and significant relationship with SME financial success.}

\section{Opportunity Competencies and SMEs financial success}

Opportunity related competencies are associated with the entrepreneurs' ability to search, develop and evaluate highquality opportunities, which are existing in a specific market (Man et al., 2002). Identifying real and effective opportunities, can avert the SMEs from potential risk and converting these opportunities into a positive outcome for SMEs is favourable for entrepreneurs' (Ahmad et al., 2010). Recognising and exploiting opportunity is one of the most critical abilities for entrepreneurs that facilitate their SMEs financial success ( Allison, Chell, \& Hayes, 2000; De Koning, 2003; Choi \& Shepherd, 2004; Bergevoet \& Woerkum, 2006; Muzychenko, 2008). SMEs entrepreneurs' should also be aware of and consider their customers' demands to ensure SMEs financial success. While, SMEs entrepreneurs' who have developed specific knowledge through education and work experience will have an advantage in terms of discovering more entrepreneurial opportunities (Bergevoet \& Woerkum, 2006), suggesting that SMEs entrepreneurs with limited education may struggle. Nasuredin et al. (2016) in his study in Malaysian context reported a positive impact of opportunity competencies on SMEs financial success as Oman is among developing economies with a large number of government tenders and contracts assigned to corporate. Thus, the government of Oman enforced the corporates that get government contracts to commit a minimum of $5 \%$ of projects amounts to SMEs as subcontractors. Hence the study hypothesises that:

\section{H3: Opportunity competencies have a positive and significant relationship with SME financial success.}

\section{Commitment Competencies and SMEs financial success}

According to Man and Lau (2000), competencies motivates the SMEs entrepreneurs to move ahead with their SMEs that enables them to sustain and enhance SMEs long-term performance. The commitment of the entrepreneurs not only drives financial gain. In a qualitative study conducted by Solesvik (2012) in context for women's entrepreneurship in Ukraine found those commitment competencies to be a driver for SMEs success and development. Commitment competencies enable entrepreneurs to be fully committed, determined and dedicated, as well as taking proactive actions towards his/her responsibilities and duties (De Tienne \& Chandler, 2004; Ahmed et al. 2010) as the majority of SMEs in Oman are run by their founders or owners who are full-time employees either in government or private sector that stimulates on their SMEs commitment level. Hence the study believes that:

\section{H4: Commitment competencies have a positive and significant relationship with SME financial success.}

\section{Relationship Competencies and SMEs financial success}

SMEs entrepreneur in Oman mostly exploiting the business opportunities from large corporates and individuals. As most of Oman's large corporates, including suppliers and customers, belongs to family businesses. Thus, SMEs entrepreneur needs to demonstrate relationship competencies in such a business environment. Noteworthy to mention that Omani society is originated from the tribal system where a relationship is embedded firmly among Omani individuals. Relationship competencies refer to the competencies related to the entrepreneur's interactions. It assists the entrepreneurs to establish contact and develop connections to exploit the business opportunities (Man \& Lau, 2000). The construct encapsulates competencies of building networks and confidence with the customers and suppliers and includes interpersonal skills, oral communication skills, relationship building, and networking (Mitchelmore \& Rowley, 2013). Referring to (Ahmad et al., 2010) while the entrepreneurs running SMEs, it is required for them to deal with the suppliers, customers, government authorities and other stakeholders. Rahman et al. (2016) found that connections and networks driven from relationship competencies enable the SMEs entrepreneurs to achieve SMEs financial success. Thus the study postulates that: 
H5: Relationship competencies have a positive and significant relationship with SME financial success.

\section{Analytical Competencies and SMEs financial success}

According to Rahman et al. (2016) analytical ability facilitates entrepreneurs in thinking differently, from new perspectives, in new ways, analytically, to cope with ambiguities, and to act on to run the business successfully. Man, Lan and Snape (2008) exploratory study have originated and introduced the analytical competencies, where conceptual competencies broke down into two sub-divisions, of which analytical competencies is one. It has also been endorsed by Chandler and Jansen (1992) it is put forward that coordinating an organisation's interests and activities can be successfully achieved through analytical competencies. Further, Man, Lau and Chan (2002) advise that unexplored opportunities may be discovered via strong analytical competencies, which help SME entrepreneurs in acquiring and developing adequate skills for analysis, decision making and problem-solving. In other words, these skills of SMEs entrepreneur are considered to be as enablers and drivers of SMEs business success. Worthwhile, SMEs entrepreneurs' need to make both quick and effective decisions while running their SMEs business due to various prompt issues and challenges. Thus, analytical competencies are deliberated as prerequisites for SMEs financial success. Therefore, it is suggested that:

\section{H 6: Analytical competencies have a positive and significant relationship with SME financial success.}

\section{Technical Competencies and SMEs financial success}

Technical competencies refer to intangible resources that assist in attaining competitive advantage (Prahalad \& Hamel, 1994; Galunic \& Rodan, 1997; Rahman et al. 2016). As stated by Pisano (1996), entrepreneurs use of technical competencies in sustaining competitive advantage and increasing venture performance. Martin and Staines (1994) emphasised that technical competencies include the ability to use and adopt technical skills, techniques and tool-handlings applicable to the business. Further, Chandler and Hanks (1994) have endorsed and emphasised that SMEs entrepreneurs would finalise their SMEs operations and tasks through possessing technical competencies. It has been further argued by Winterton (2002) that the entrepreneur must have the technical skill (know-how), knowledge and ability to obtain technical skills to carry out their business which refers to technical competencies. Technical competencies are being considered as essential elements for any kind of entrepreneurial business success. Besides, Ahmad, Halim and Zainal (2010), considered technical competencies which are knowledge possessions of instrument and tools, machines and expertise of the work as a requirement for entrepreneurial business success. Such possession and expertise of knowledge and work are considered to convey financial success for SMEs. Thus, considering the context of the study, the present study also hypothesises that:

\section{H 7: Technical competencies have a positive and significant relationship with SME financial success.}

\section{Innovative Competencies and SMEs financial success}

Man, Lau and Chan (2002) have described innovative competencies as the aptitude to be innovative in new products, services or processes in the business. Innovative competencies have been derived from the study of Man, Lan and Snape (2008), where the researchers divided conceptual competencies into two sub-divisions, of which innovative competencies is one. Scholars have specified that continues search for innovative solutions would deliver a competitive advantage that drives to firm business success (Zaugg \& Thom, 2002). In line with RBV, the valuable innovative capabilities of an entrepreneur can facilitate firm performance (Barney, 1991; Grant, 1991). Therefore, it is expected that innovative competencies will support SMEs to become financially successful. Thus the study hypothesises that:

H 8: Innovative competencies have a positive and significant relationship with SME financial success.

\section{Moderating effect of firm resources availability on financial literacy and entrepreneur competencies relationship with SMEs financial success.}

Founder or Owner abilities to gather resources and use them, as well as the overall availability of resources; which are primary inputs into the production process including items of capital equipment, skills of individual employees, finance, and so on. (Chandler \& Hanks, 1994). According to RBV theory, these internal firm resources are endowment for competitive advantage resulting in business success (Barney, 1991). Therefore, as an important implication for scholars of (EC) is the need to consider the contingent role of resources internal to the SMEs. Hofer and Schendel (1978) sated that financial resources, physical resources, human resources, firm resources, and technological resources helped firms to achieve their goals.

Further, previous researches (Edelman, Brush \& Manolova, 2002; Lau, 2011; Albrecht, Breidahl \& Marty, 2018) has studied the role of firm resources in different contexts and confirmed that organisational resources have a positive relationship with firms performance and its sustainability. Besides, Leonidou, Palihawadana, and Theodosiou, (2011) have adopted the firm resources, as a mediator, to study its effect on strategy, competitive advantage, and firm performance in the context of the export industry. The current research considers SMEs firm resources that comprise of 
human resources, capital resources, monetary resources and raw materials that would enable in the endowment of competitive advantage, which drives SMEs financial success. In Oman, most of SMEs has eased to credit facilities the collateral or security to cover the credit facility remains one of the main constrain form SMEs financial resources.

Besides, due to governments' Omanization policies, it becomes difficult for SMEs to obtain a sufficient number of skilled ex-pat labour. According to Yassir Al Bosafi, the Head of labour Work permits, "Oman's Ministry of Manpower has determined the Omanization requirements from SMEs in phases as the Omanization should not be less than 25\%, $50 \% 75 \%$ for the first, second, third year respectively and $100 \%$ Omanization in the fourth year is required and to be maintained. However, the ministry of manpower based on the ministerial decree of (103/2015) can give two years exception for SMEs that have fully committed entrepreneurs' who are not occupying jobs in government or private sector" ( SMEs Manpower Law, 2015). While there is always constrain from limited skill pool among Omani labour market. Besides the enhancement in the minimum paid salary of OMR 325/- that increases the burden of Oman's SMEs. While there are high tariffs and tax on certain raw materials imported by the SMEs beside the limited number of local raw material suppliers due to dominates of family businesses on the local market. While, as a theoretical gap in previous researches related to entrepreneurs' competencies (EC) and SMEs financial success, this research is intended to adapt the firm resources availability as moderator. Hence, this study hypothesises that:

H 9.1: Firm Resources Availability moderates the relationship between Financial Literacy and SME financial success. $H$ 9.2: Firm Resources Availability moderates the relationship between Strategic Competencies and SME financial success.

H 9.3 Firm Resources Availability moderates the relationship between Opportunity Competencies and SME financial success.

H 9.4: Firm Resources Availability moderates the relationship between Commitment Competencies and SME financial success.

H 9.5: Firm Resources Availability moderates the relationship between Relation Competencies and SME financial success.

H 9.6: Firm Resources Availability moderates the relationship between Analytical Competencies and SME financial success.

H 9.7: Firm Resources Availability moderates the relationship between Technical Competencies and SME financial success.

$H$ 9.8: Firm Resources Availability moderates the relationship between Innovation competencies and SME financial success.

\section{Moderating effect of government support on financial literacy and entrepreneur competencies relation with SMEs financial success.}

Under Oman Vision 2040, SMEs take first place in government plans. This privilege for SMEs is intensified by His Majesty Sultan Haitham bin Tarik Al Said in his first speech to Omani public emphasising on the significant role of SMEs in the nation's economy. He further asserted to enhance the government support to flourish SMEs in Oman. According to Shamsuddin, Sarkawi, Jaafar, and Abdul Rahim (2017), government support is the government efforts and involvement to provide SMEs with financial, non-financial support and other services. Whereas, government support would play a prominent role in promoting SMEs due to the significant contribution of SMEs to nations economy in terms of economic diversification, job creation and wealth distribution among the citizens. The scholars in previous research indicated that government support to SMEs comprises government business support, financial support and non-financial support (Shamsuddin et al. 2017).

Further, the moderating role of government support has been studied by (Bahari, Yunus \& Jabar, 2017) in context of entrepreneurial orientation (EO) and SMEs success relationship and it confirmed the meaningful influence of government support. As the theoretical gap in previous researches related to entrepreneurs' competencies (EC) and SMEs financial success, this research intended to adapt the government support as a moderator. Hence, this study hypothesises that:

H10.1: Government Support moderates the relationship between Financial Literacy and SME financial success. H 10.2: Government Support moderates the relationship between Strategic Competencies and SME financial success. H 10.3: Government Support moderates the relationship between Opportunities Competencies and SME financial success.

H 10.4: Government Support moderates the relationship between Commitment Competencies and SME financial success. H 10.5: Government Support moderates the relationship between Relation Competencies and SME financial success.

H 10.6: Government Support moderates the relationship between Analytical Competencies and SME financial success. H 10.7: Government Support moderates the relationship between Technical Competencies and SME financial success. H 10.8: Government Support moderates the relationship between Innovation competencies and SME financial success. 


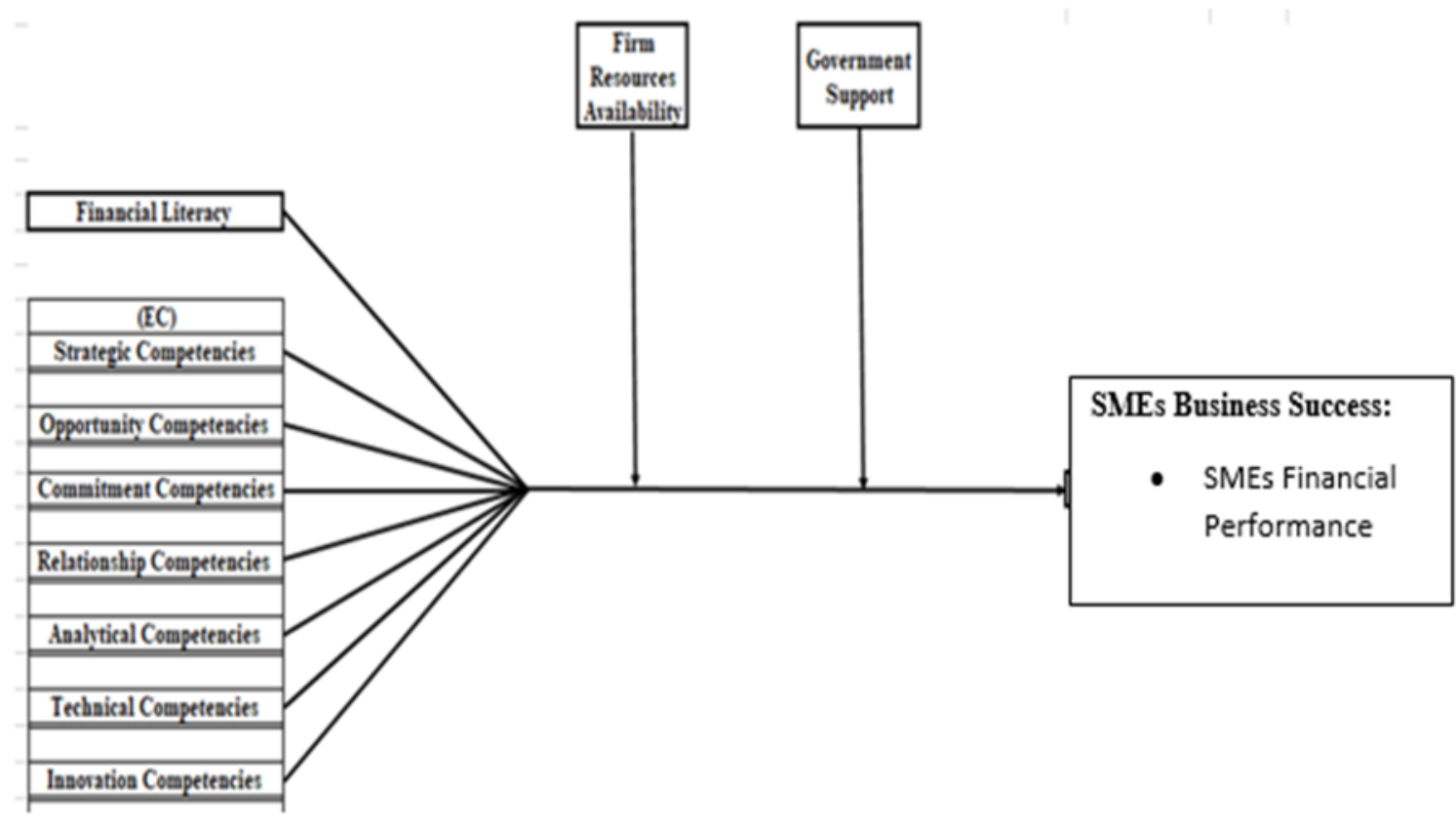

Figure 2 Conceptual Framework on financial literacy and entrepreneur competencies relationship with Oman's SMEs Business Success captioned by SMEs financial Performance with the moderating effect of firm resources availability and government support.

The research framework of the study is conceptualised based on previous literature and the underlying theory to be used in the study. The conceptual framework explains the relationship of financial literacy, strategic competencies, opportunity competencies, commitment competencies, relationship competencies, analytical competencies, Technical competencies and innovative competencies with SMEs financial success.

\section{METHODOLOGY}

\section{Research Design}

Research design is a general strategy for carrying out scientific research. It represents the basic structure of the study (Salkind, 2010). The design serves as a guide to the researcher in the research procedures, particularly in gathering, analysing and interpreting the data. Salkind (2010) also mentions that research designs enable the researcher to answer research questions as to validity, objectivity, accurately and economically as possible. This research is concerned with the antecedents and outcomes of financial literacy and entrepreneur competencies (EC) relationship with SMEs financial success. This study will also analyse the moderating effect of firm resources availability and government support. This study deploys a cross-sectional quantitative approach to achieve the research objectives and the research questions.

According to Sekaran and Bougie (2003), cross-sectional quantitative is categorised as a field study. A cross-sectional study is one of the best ways to determine commonness and is useful at identifying associations among variables (Mann, 2003). In this context, field study encompasses scientific inquiry aimed at revealing the relationship and interactions between the antecedents and the outcomes of the variables. The cross-sectional study can be done in which data are gathered over a while to answer research questions (Sekaran \& Bougie, 2003). One of the advantages of this crosssectional study is that subjects are neither exposed nor treated, and there are seldom ethical difficulties. This method will be chosen since the researcher tends to gather perceptions of the respondents about situations that have already occurred, and variables/factors cannot be manipulated. Selection of a suitable model for enquiry depends on the research question and the nature of the appropriate answer; in this study, the hypotheses call for a quantitative research method, data collection and analysis (Lincoln \& Denzin, 2000). 
Since this is an empirical study, a structural approach for data collection and analysis will be used to address the problem discussed in this research. In total, nine elements of research design given by Sekaran and Bougie (2010) to be used in this research. These nine elements are the purpose of the research, type of investigation, extent of researcher's interference, study setting, and unit of analysis, sampling design, time horizon, data collection method, and measurement of variables. The research design is based on a quantitative research approach and uses hypothesis testing method. The research design of the research quantified the evidence related to the research found in the literature review. Table 3.1 detailed the dimensions of the research design to be used in the research study.

Table 2 Dimensions of Research Design

\begin{tabular}{cll}
\hline SN. & Study Dimension & Details of the Study \\
\hline 1 & Purpose of the research & Hypothesis testing \\
2 & Types of investigation & Correlational relationship \\
3 & The extent of the researcher's interference & Minimal; studied events that generally occur \\
4 & Study setting & Non-contrived; field study \\
5 & Unit of analysis & SMEs Businesses \\
6 & Sampling design & Non-random sampling (convenience sampling) \\
7 & Time horizon & Cross-sectional \\
8 & Data-collection method & Quantitative (survey) \\
9 & Measurement of variable & Element definition, interval scale (seven-point and \\
& & five-point Likert scale), nominal \\
\hline
\end{tabular}

\section{Research Sites/Population}

The area of the study includes SMEs in Oman. The identification of the target population is the first step in the sampling process. The process of identifying the target population should be specific and relevant to the research project under investigation (Sekaran \& Bougie, 2003). The population of the research indicates to the whole group of individuals, things, or event, of interest that researcher prepared to investigate (Sekaran \& Bougie, 2010). According to Engineer Naif Al Balushi, Head of SMEs development and support in Riyada, "Oman has 42,163 SMEs including small and medium". (SMEs businesses' growth, 2019).

\section{Unit of analysis}

Based on Sekaran (2006), the unit of analysis is the level of aggregation of data collected during data analysis. Therefore, the unit of analysis for this study is SMEs business. Most of Oman's SMEs are managed by their owners, as SMEs owners have full authority and discretionary power to decide to ensure their SMEs financial success. Thus, only one set of questionnaires will be sent to each SMEs.

\section{Sample size and Sampling Method}

Sekaran (2006) defines the sampling frame as a list of all elements in a population. According to Sekaran (2006), by studying the sample, the researcher should be able to draw conclusions that would be generalisable to the population of interest. Similarly, Babbie (2004) indicated that sampling is the process of selecting observations from the population. Sekaran and Bougie (2010) suggested that sample size some-where between 30 to 500 would be useful for most of the research. In support, Roscoe (1975) stated the appropriate sample size should be higher than 30 and less than 500. The minimum sample size was also established by $\mathrm{G}^{*}$ Power calculation as the study has a maximum eight predictors pointing towards one endogenous variable, medium effect size and 0.95 power of the model was set to calculation. The G*Power calculation resulted in 133 as the minimum sample size for the research model of the study. At the same time, this study is considering Hoe (2008) argument on minimum sample size and his recommendation to make that sample size more 
than 200 to provide enough statistical power for data analysis. Thus, the present research proposed 200 SMEs in Oman as an adequate sample size. In social science research, the usual response rate is within $15 \%$ to $20 \%$ (Bhattacherjee, 2012). Naing, Winn and Rusli (2006) mentioned that the numbers of the questionnaire sent in a study should be increased by $20 \%$ than the appropriate sample size to offset for nonresponse. It could be safely concluded that within all the conditions given above the number of questionnaires to be distributed will be 300 .

Sampling is primarily a method in which some of the elements from the population is selected and conclude to implement on the entire population (Cooper \& Schindler, 2009). A non-probability convenience sampling to be used to collect the data for the study. Convenience sampling is the most frequently used technique in quantitative studies. However, by using this technique, the opportunity to participate is not equal for all qualified individuals in the target population (Suen, Huang, \& Lee, 2014). Convenience sampling is the least rigorous technique which involves most easily available subjects. It is least costly in terms of time, money, and efforts to the researcher (Bryman \& Bell, 2011). In comparison to probability samplings, convenience sampling is conventional and frequently used in business and management research (Bryman, 2003).

\section{Survey Instruments}

The current study is cross-sectional. It is a type of observational study design in which the investigator measures the outcome and the exposures in the study participants at the same time. The participants in a cross-sectional study are just to be selected based on the inclusion and exclusion criteria set for the study. Cross-sectional designs are used for population-based surveys (Setia, 2016). Data collection is a necessary and early step in the research process (Babbie, 2001). Data sources are either primary or secondary. As Questionnaires are widely used to collect primary data that is particularly suitable for unexplored research areas and when secondary data is not readily available Survey research collects primary data by asking respondents for information (Zikmund, 2003). A survey is a method of collecting data based on communication with a representative sample of individuals. The individuals selected to answer questions are called respondents (Zikmund, 2003). Using a survey is inexpensive, quick, efficient and generally accurate in getting information about the sample population.

Thus, data will be collected in the form of a set of questionnaire through drop off / Pick up for SMEs in Oman. Through this method, researchers will attempt to make face-to-face contact with the respondent by hand, delivering the questionnaire. Researchers return later to pick-up the questionnaire in-person and at a designated time (Allred \& RossDavis, 2011). According to Maclennan, Langley, and Kypri (2011), drop off / pick up method reduces interviewer bias effects and social desirability effects and exploits the benefit of leaving respondents alone and in their own time. However, the main limitation of drop off / pick up method is that it can be challenging to determine whether the eligible individual completed the questionnaire, the same limitation in mail surveys. (Allred \& Ross-Davis, 2011).

\section{EXPECTED OUTCOMES/FINDINGS FOR RESEARCH PROPOSITION}

The expected outcomes/ findings of the present research propositions could be summarised into closing the theoretical and knowledge gaps caused by inconsistencies from previous research findings related to significant and effect of entrepreneurs competencies (EC) sub-dimension effect on SMEs financial success. Besides, the present research is expected to validate and confirm the moderating role of firm resources availability and government support on SMEs financial success. Last but not least, this paper accumulates the findings in resource-based view theory and enriches the entrepreneurship literature, particularly in the context of SMEs in developing economies. For future research direction; future studies should identify ways to obtain entrepreneurs' competencies (EC) and financial literacy data from multiple informants to minimise the possibility of response bias.

\section{CONCLUSION}

This research examines the relationship of entrepreneur competencies (EC) sub-dimensions and financial literacy with SMEs financial success. Besides, to the moderating role of firm resources availability and government support on SMEs financial success. The research applies a quantitative research method. Data will be collected from SMEs founders/owners using questionnaires and analysed by applying the PLS-SEM as a statistical tool.

\section{REFERENCES} $\begin{aligned} & \text { Adcorp (2012). } \\ & \text { http://www.adcorp.co.za/NEws/Pages/Newbusinessstartupsslumptoall-timelow.aspx. }\end{aligned}$ New
Business

Adomako, S., \& Danso, A. (2014). Regulatory environment, environmental dynamism, political ties, and performance: Study of entrepreneurial firms in a developing economy. Journal of Small Business and Enterprise Development, 21(2), 212-230. 
Adomako, S., Danso, A., \& Ofori Damoah, J. (2016). The moderating influence of financial literacy on the relationship between access to finance and firm growth in Ghana. Venture Capital, 18(1), 43-61.

Ahmad, N. H. (2007). A cross-cultural study of entrepreneurial competencies and entrepreneurial success in SMEs in Australia and Malaysia (Doctoral dissertation).

Ahmad, N. H., Suseno, Y., Seet, P. S., Susomrith, P., \& Rashid, Z. (2018). Entrepreneurial competencies and firm performance in emerging economies: A study of women entrepreneurs in Malaysia. In Knowledge, learning and innovation (pp. 5-26). Springer, Cham.

Al Lawati H. (2019, January 2). What do we want from SMEs? Muscat: Oman Observer. p. 9

Al Mamun, A., Fazal, S.A. and Muniady, R. (2019), "Entrepreneurial knowledge, skills, competencies and performance: A study of micro-enterprises in Kelantan, Malaysia", Asia Pacific Journal of Innovation and Entrepreneurship, 13(1), $29-48$.

Albrecht, S., Breidahl, E., \& Marty, A. (2018). Organisational resources, organizational engagement climate, and employee engagement. Career Development International, 23(1), 67-85.

Al-Damen, R. A. (2015). The impact of entrepreneurs' characteristics on small business success at medical instruments supplies organisations in Jordan. International Journal of Business and Social Science, 6(8), 164-175

Allison, C. W., Chell, E., \& Hayes, J. (2000). Intuition and entrepreneurial behavior. European Journal of Work and Organizational Psychology, 9(1), 31-43.

Allred, S. B., \& Ross-Davis, A. (2011). The drop-off and pick-up method: An approach to reduce nonresponse bias in natural resource surveys. Small-Scale Forestry, 10(3), 305-318.

Babbie, E. (2004). The Practice of Social Research Thomson. Wadsworth: California.

Bae, T. J., Qian, S., Miao, C., \& Fiet, J. O. (2014). The relationship between entrepreneurship education and entrepreneurial intentions: A meta-analytic review. Entrepreneurship theory and practice, 38(2), 217-254.

Bahaddad, A. A., AlGhamdi, R., \& Houghton, L. (2012). To what extent would E-mall enable SMEs to adopt e-commerce?. International Journal of Business and Management, 7(22), 123-132

Bahari, N., Jabar, J., \& Yunus, A. R. (2017). Malaysian women entrepreneurial characteristics, strategic orientation and firm performance: The moderator role of government support programs. International Journal of Advanced and Applied Sciences, 4(12), 257-262.

Banks, J., C. O’Dea, and Z. Oldfield. (2010). Cognitive Function, numeracy and Retirement Saving Trajectories. The Economic Journal 120 (548): F381-F410.

Barazandeh, M., Parvizian, K., Alizadeh, M., \& Khosravi, S. (2015). Investigating the effect of entrepreneurial competencies on business performance among early stage entrepreneurs Global Entrepreneurship Monitor (GEM 2010 survey data). Journal of Global Entrepreneurship Research, 5(1), 1-12.

Barney, J. (1991). Firm resources and sustained competitive advantage, Journal of Management, 17(1), 99-120.

Barney, J. B. (1986). Strategic factor markets: Expectations, luck, and business strategy. Management Science, 32(10), $1231-1241$.

Bergevoet, R. H. M., \& Woerkum, C. V. (2006). Improving the entrepreneurial competencies of Dutch dairy farmers through the use of study groups. Journal of Agricultural Education and Extension, 12(1), 25-39.

Bhattacherjee, A. (2012). Social science research: Principles, methods, and practices.

Bird, B. (1995). Towards a theory of entrepreneurial competency. Advances in entrepreneurship, firm emergence and growth, 2(1), 51-72.

Bird, B. (2019). Toward a theory of entrepreneurial competency. In Seminal Ideas for the Next Twenty-Five Years of Advances (pp. 115-131). Emerald Publishing Limited.

Brinckmann, J., Grichnik, D., \& Kapsa, D. (2010). Should entrepreneurs plan or just storm the castle? A meta-analysis on contextual factors impacting the business planning-performance relationship in small firms. Journal of Business Venturing, 25(1), 24-40.

Brüderl, J., \& Preisendörfer, P. (1998). Network support and the success of newly founded business. Small business economics, 10(3), 213-225.

Bryman, A. (2003). Quantity and quality in social research (Vol. 18). Routledge. 
Bryman, A., \& Bell, E. (2011). Ethics in business research. Business Research Methods, 7(5), 23-56.

Chandler, G. N., \& Hanks, S. H. (1994). Market attractiveness, resource-based capabilities, venture strategies, and venture performance. Journal of business venturing, 9(4), 331-349.

Chandler, G. N., \& Jansen, E. (1992). The founder's self-assessed competence and venture performance. Journal of Business Venturing, 7(3), 223-236.

Choi, Y. R. \& Shepherd, D. A. (2004). Entrepreneurs' decisions to exploit opportunities. Journal of Management, 30(3), $377-395$.

Christelis, D., Jappelli, T., \& Padula, M. (2010). Cognitive abilities and portfolio choice. European Economic Review, 54(1), $18-38$.

Cochran, W. G. (2007). Sampling techniques. John Wiley \& Sons.

Collis, D. J., \& Montgomery, C. A. (1995). Competing on Resources: Strategy in the 1990s. Knowledge and strategy, 73(4), 25-40.

Coltman, T., Devinney, T. M., Midgley, D. F., \& Venaik, S. (2008). Formative versus reflective measurement models: Two applications of formative measurement. Journal of Business Research, 61(12), 1250-1262.

Conner, K. R. (1991). A historical comparison of resource-based theory and five schools of thought within industrial organisation economics: do we have a new theory of the firm?. Journal of Management, 17(1), 121-154.

Cooper, D., \& Schindler, P. (2009). Research Methodology and Design.

Dahmen, P., \& Rodríguez, E. (2014). Financial Literacy and the Success of Small Businesses: An Observation from a Small Business Development Center. Numeracy: Advancing Education in Quantitative Literacy, 7(1). 1-12.

Darcy, C., Hill, J., McCabe, T., \& McGovern, P. (2014). A Consideration of organisational sustainability in the SME context. European Journal of Training and Development, 38(5), 398-414.

De Koning, A. (2003) Opportunity development: A socio-cognitive perspective, (eds) Katz, J. A. and Shepherd, D. A. Advances in entrepreneurship, firm emergence and growth: Cognitive approaches to entrepreneurship research vol. 6, 265-314. Elsevier, Oxford.

Dess, G. G., \& Robinson Jr, R. B. (1984). Measuring organizational performance in the absence of objective measures: the case of the privately-held firm and conglomerate business unit. Strategic Management Journal, 5(3), $265-273$.

DeTienne, D. R., \& Chandler, G. N. (2004). Opportunity identification and its role in the entrepreneurial classroom: A pedagogical approach and empirical test. Academy of Management Learning \& Education, 3(3), 242-257.

Drexler, A., Fischer, G., \& Schoar, A. (2014). Keeping it simple: Financial literacy and rules of thumb. American Economic Journal: Applied Economics, 6(2), 1-31.

Driessen, M. P., \& Zwart, P. S. (2007). The entrepreneur scan measuring characteristics and traits of entrepreneurs. Available from Internet:< http://www. necarbo. eu/files/E-scan\% 20MAB\% 20Article. pdf.

Dzomonda, O., \& Fatoki, O. (2019). The Role of Institutions of Higher Learning towards Youth Entrepreneurship Development in South Africa. Academy of Entrepreneurship Journal, 25(1), 1-11.

Edelman, L. F., Brush, C. G., \& Manolova, T. S. (2002). The impact of human and organisational resources on small firm strategy. Journal of small business and enterprise development, 9(3), 236-244.

Ekpe, I., Mat, N. B., \& Razak, R. C. (2010). The effect of microfinance factors on women entrepreneurs' performance in Nigeria: A conceptual framework. International Journal of Business and Social Science, 1(2), 255-263.

Eniola, A. A., \& Entebang, H. (2016). Financial literacy and SME firm performance. International Journal of Research Studies in Management, 5(1), 31-43.

Eniola, A. A., \& Entebang, H. (2017). SME managers and financial literacy. Global Business Review, 18(3), 559-576.

Fong, C., Ocampo, L. E., \& Alarcón, A. M. (2011). The SME in Mexico: the case of born global and spin-off firms. In The 2011 Barcelona European Academic Conference (pp. 465-478).

Francis, M. M., \& Willard, M. (2016). Unlocking the potential of information and communication technology for business sustainability by small, micro and medium enterprises in Vhembe District, South Africa. IADIS International Journal on Computer Science \& Information Systems, 11, 41-48. 
Franco, M., Haase, H. and Lautenschläger, A. (2010), Students' entrepreneurial intentions: an inter-regional comparison, Education + Training, 52(4), 260-275.

Galunic, C., \& Rodan, S. (1997). Resource recombinations in the firm: knowledge structures and the potential for Schumpeterian innovation. Insead.

Grant, R. M. (1991). The resource-based theory of competitive advantage: implications for strategy formulation. California Management Review, 33(3), 114-135.

Gray, B., Gash, M., Revees, S., \& Crookston, B. (2011). Microfinance: A sustainable platform for non-financial services, progress in economics research (Vol. 20). Hauppauge: Nova Science.

Griffin, R. W. (2012), “Managing New Venture Formation and Entrepreneurship”, In Griffin,R. W. (Ed.), Management: Principles and Practices: South-Western, Cengage Learning.

Hair Jr, J. F., Black, W. C., Babin, B. J., Anderson, R. E., \& Tatham, R. L. (2010). SEM: An introduction. Multivariate data analysis: A Global Perspective, 5(6), 629-686.

Halim, H. A., Ahmad, N. H., \& Ramayah, T. (2019). Sustaining the Innovation Culture in SMEs: The Importance of Organisational Culture, Organisational Learning and Market Orientation. Asian Journal of Business Research, 9(2), 14-33.

Hamel, G., \& Prahalad, C. K. (1996). Competing for the Future. Harvard Business Press.

Hazlina Ahmad, N., Ramayah, T., Wilson, C., \& Kummerow, L. (2010). Is entrepreneurial competency and business success relationship contingent upon business environment? A study of Malaysian SMEs. International Journal of Entrepreneurial Behavior \& Research, 16(3), 182-203.

Hilgert, M. A., Hogarth, J. M., \& Beverly, S. G. (2003). Household financial management: The connection between knowledge and behavior. Fed. Res. Bull., 89, 309.

Hoe, S. L. (2008). Issues and procedures in adopting structural equation modelling technique. Journal of Applied Quantitative Methods, $3(1), 76-83$.

Hofer, C. W. D., Schendel (1978). Strategy Formulation: Analytical Concepts. West Publishing, St. Paul, MN.

Hsieh, F. Y., Lavori, P. W., Cohen, H. J., \& Feussner, J. R. (2003). An overview of variance inflation factors for sample-size calculation. Evaluation \& the Health Professions, 26(3), 239-257.

Insights, F. (2010). Small and Medium-Sized Enterprises: Rebuilding a Foundation for Post-Recovery Growth. Certified General Accountants Association of Canada.

Jacob, M., Johan, S., Schweizer, D., \& Zhan, F. (2016). Corporate finance and the governance implications of removing government support programs. Journal of Banking \& Finance, 63, 35-47.

Jarvis, C.B, MacKenzie, S.B., and Podsakoff, P.M. (2003), "A critical review of construct indicators and measurement model misspecification in marketing and consumer research", Journal of Consumer Research, 30(2), pp. 199-218.

Karlan, D., \& Valdivia, M. (2011). Teaching entrepreneurship: Impact of business training on microfinance clients and institutions. Review of Economics and Statistics, 93(2), 510-527.

Kodongo, O. (2018). Financial regulations, financial literacy, and financial inclusion: Insights from Kenya. Emerging Markets Finance and Trade, 54(12), 2851-2873.

Lau, C. M. (2011). Team and organisational resources, strategic orientations, and firm performance in a transitional economy. Journal of Business Research, 64(12), 1344-1351.

Leonidou, L. C., Palihawadana, D., \& Theodosiou, M. (2011). National export-promotion programs as drivers of organisational resources and capabilities: effects on strategy, competitive advantage, and performance. Journal of International Marketing, 19(2), 129.

Lerner, M., \& Almor, T. (2002). Relationships among strategic capabilities and the performance of women-owned small ventures. Journal of Small Business Management, 40(2), 109-125.

Lincoln, Y. S., \& Denzin, N. K. (Eds.). (2000). Handbook of qualitative research (pp. 163-188). Thousand Oaks, CA: Sage.

Lusardi, A. (2019). Financial literacy and the need for financial education: evidence and implications. Swiss Journal of Economics and Statistics, 155(1), 1-8. 
Lusardi, A., \& Bassa Scheresberg, C.D. (2013). Financial literacy and high-cost borrowing in the United States (Working Paper Series/National Bureau of Economic Research). Cambridge, MA: National Bureau of Economic Research.

Lusardi, A., and O. Mitchell. (2011). "Financial Literacy and Planning: Implications for Retirement Wellbeing." In Financial Literacy: Implications for Retirement Security and the Financial Marketplace, edited by A. Lusardi and O. Mitchell, 17-39, Oxford: Oxford University Press

Maclennan, B., Langley, J., \& Kypri, K. (2011). Distributing surveys: Postal versus drop-and-collect. Epidemiology, 22(3), $443-444$.

Madhani, P. M. (2009). Resource-based view (RBV) of competitive advantages: Importance, issues and implications. KHOJ Journal of Indian Management Research and Practices, 1(2), 2-12.

Man, T. W. Y., Lau, T., \& Chan, K. F. (2002). The competitiveness of small and medium enterprises: A conceptualisation with focus on entrepreneurial competencies. Journal of Business Venturing, 17(2), 123-142.

Man, T. W. Y., Lau, T., \& Snape, E. (2008). Entrepreneurial competencies and the performance of small and medium enterprises: An investigation through a framework of competitiveness. Journal of Small Business \& Entrepreneurship, 21(3), 257-276.

Man, T. W., \& Lau, T. (2000). Entrepreneurial competencies of SME owner/managers in the Hong Kong services sector: A qualitative analysis. Journal of Enterprising Culture, 8(03), 235-254.

Mandell, L., \& Hanson, K. O. (2009, January). The impact of financial education in high school and college on financial literacy and subsequent financial decision making. In American Economic Association Meetings, San Francisco, CA (Vol. 51).

Mandl, I., Hurley, J., Ledermaier, S., \& Napierala, J. (2016). Job Creation in SMEs: ERM Annual Report 2015. Publications Office of the European Union.

Mann, C. J. (2003). Observational research methods. Research design II: cohort, cross-sectional, and case-control studies. Emergency Medicine Journal, 20(1), 54-60.

Martin, G. and Staines, H. (1994), "Managerial Competences in Small Firms", Journal of Management Development, 13(7), 23-34

Miller M, Godfrey N, Levesque B, Stark E (2009). The Case for Financial Literacy in Developing Countries: Promoting Access to Finance by Empowering Consumers.

Mitchelmore, S., \& Rowley, J. (2013). Entrepreneurial competencies of women entrepreneurs pursuing business growth. Journal of small business and enterprise development, 20(1), 125-142.

Morgan, R. E., \& Strong, C. A. (2003). Business performance and dimensions of strategic orientation. Journal of Business Research, 56(3), 163-176.

Muzychenko, O. (2008). Cross-cultural entrepreneurial competence in identifying international business opportunities. European Management Journal, 26(6), 366-377.

Naing, L., Winn, T., \& Rusli, B. N. (2006). Practical issues in calculating the sample size for prevalence studies. Archives of Orofacial Sciences, 1, 9-14.

Nasir, W. M. N. B. W. M., Al Mamun, A., \& Breen, J. (2017). Strategic orientation and performance of SMEs in Malaysia. SAGE Open, 7(2), 1-13

Nasuredin, J., Halipah, A. H., \& Shamsudin, A. S. (2016). Entrepreneurial Competency and SMEs Performance in Malaysia: Dynamic Capabilities as Mediator. International Journal of Research, 3(4), 4759-4770

Ng, H. S., \& Kee, D. M. H. (2018). The core competence of successful owner-managed SMEs. Management Decision, 56(1), 252272.

Ng, HS (2016). 'The Influence of Transformational Leadership and Competence on Small Enterprise Success in Malaysia: The Mediating Effective of Innovativeness'. (Unpublished PhD Thesis), Universiti Sains Malaysia, Malaysia.

Okello Candiya Bongomin, G., Mpeera Ntayi, J., Munene, J.C. and Akol Malinga, C. (2017), "The relationship between access to finance and growth of SMEs in developing economies: Financial literacy as a moderator", Review of International Business and Strategy, 27(4), 520-538.

OECD. (2010). ‘SMEs, Entrepreneurship and Innovation'. OECD Studies on SMEs and Entrepreneurship, OECD Publishing, Paris Oman Non-Performing Loan Ratio (2019, December 25). Retrieved from https://www.ceicdata.com/en/indicator/oman/nonperforming-loans-ratio 
Perren, L. (2000). Factors in the growth of micro-enterprises (part 2): exploring the implications. Journal of Small Business and Enterprise Development, 7(1), 58-68.

Pisano, G. P. (1996). Learning-before-doing in the development of new process technology. Research Policy, 25(7), $1097-1119$.

Prahalad, C. K., \& Hamel, G. (1994). Strategy as a field of study: Why search for a new paradigm?. Strategic management journal, 15 (S2), 5-16.

Rahbi, A. L., \& Abdullah, H. S. (2017). Factors influencing social media adoption in small and medium enterprises (SMEs) (Doctoral dissertation, Brunel University London).

Rahman, S. A., Ahmad, N. H., \& Taghizadeh, S. K. (2016). Entrepreneurial competencies of BoP entrepreneurs in Bangladesh to achieve business success. Journal of General Management, 42(1), 45-63.

Remund, D. L. (2010). Financial literacy explicated: The case for a clearer definition in an increasingly complex economy. Journal of consumer affairs, 44(2), 276-295.

Ringle, C., Sarstedt, M., and Straub, D. (2012), "A Critical Look at the Use of PLS-SEM in MIS Quarterly", MIS Quarterly (MISQ), $36(1), 3-14$.

Ropega, J. (2011). The Reasons and Symptoms of Failure in SME. International Advances in Economic Research, 17(4), 476-483.

Roscoe, J. T. (1975). Fundamental research statistics for the behavioral sciences [by] John T. Roscoe.

S. Ahmad, N. H. Ahmed, Halim, H. A., \& Zainal, S. R. M. (2010). Is Entrepreneurial Competency the Silver Bullet for SME Success in a Developing Nation? International Business Management, 4(2), 67-75.

Salkind, N. J. (Ed.). (2010). Encyclopedia of research design (Vol. 1). Sage.

Santos, J. B., \& Brito, L. A. L. (2012). Toward a subjective measurement model for firm performance. BAR-Brazilian Administration Review, 9(SPE), 95-117

Sekaran, U. (2006). Research methods for business: A skill-building approach. John Wiley \& Sons

Sekaran, U. Bougie (2010). Research methods for business: A skill-building approach.

Sekaran, U., \& Bougie, R. (2003). Research Methods for Business, A Skill Building Approach, John Willey \& Sons. Inc. New York.

Setia, M. S. (2016). Methodology series module 3: Cross-sectional studies. Indian journal of dermatology, 61(3), 261.

Shamsuddin, J., Sarkawi, M. N., Jaafar, A. R., \& Abd Rahim, N. F. (2017). Malaysian SMEs Performance and the Government Business Support Service: The Moderating Effects of Absorptive Capacity. International Journal of Supply Chain Management, 6(4), 326-331.

Singh, S., Darwish, T. K., \& Potočnik, K. (2016). Measuring organisational performance: A case for subjective measures. British Journal of Management, 27(1), 214-224.

SMEs \& Manpower Law (2015, December 20). Oman Info Portal. Retrieved from http://omaninfo.om/topics/60/show/30431

SMEs businesses growth (2019, September 4). Atheer News. Retrieved from https://www.atheer.om/archives/505774/

SMEs in Oman (2019, December 20) Public Authority for SME Development Oman, Retrieved from: https://riyada.om/arom/Pages/Home.aspx/

Smith, J. P., McArdle, J. J., \& Willis, R. (2010). Financial decision making and cognition in a family context. The Economic Journal, 120(548), F363-F380.

Solesvik, M. Z. (2013). Entrepreneurial motivations and intentions: investigating the role of education major. Education+ Training, 55(3), 253-271.

Stonehouse, G., \& Pemberton, J. (2002). Strategic planning in SMEs-some empirical findings. Management Decision, 40(9), 853-861.

Suen, L. J. W., Huang, H. M., \& Lee, H. H. (2014). A comparison of convenience sampling and purposive sampling. Hu Li Za Zhi, 61(3), 105-111. 
Tanoira, F. G. B., \& Valencia, R. A. S. (2014). Knowledge Management, Entrepreneurial Competencies and Organizational Development in Micro and Small Enterprises in Rural Regions in The State of Yucatan, Mexico. European Scientific Journal, ESJ, 10(1).

Tehseen, S. and Ramayah, T. (2015), Entrepreneurial competencies and SMEs business success: the contingent role of external integration, Mediterranean Journal of Social Sciences, 60(1), .50-61.

Tenenhaus, M., Amato, S., \& Esposito Vinzi, V. (2004, June). A global goodness-of-fit index for PLS structural equation modelling. In Proceedings of the XLII SIS scientific meeting (Vol. 1, No. 2, pp. 739-742).

Tenenhaus, M., Vinzi, V. E., Chatelin, Y. M., \& Lauro, C. (2005). PLS path modeling. Computational statistics \& data analysis, 48(1), 159-205.

Van Rooij, M., Lusardi, A., \& Alessie, R. (2011). Financial literacy and stock market participation. Journal of Financial Economics, 101(2), 449-472.

Voegtle, M. G. L., Spaulding, D. T., \& Katherine, H. (2006). Methods in Educational Research.

Wernerfelt, B. (1984). A resource-based view of the firm. Strategic Management Journal, 5(2), 171-180.

Winterton, J., \& Winterton, R. (2002). Developing managerial competence. Routledge.

Wise, S. (2013). The impact of financial literacy on new venture survival. International Journal of Business and Management, 8(23), 30-39.

Yoong, J. (2011). Financial illiteracy and stock market participation: Evidence from the RAND American Life Panel. Financial literacy: Implications for retirement security and the financial marketplace, 76.

Yoong, J., 2011. “Financial Illiteracy and Stock Market Participation: Evidence from the- American Life Panel.” In Financial Literacy: Implications for Retirement Security and the Financial Marketplace, edited by Olivia S.Mitchell and Annamaria Lusardi, 76-97. Oxford: Oxford University Press

Zaridis, A. D., \& Mousiolis, D. T. (2014). Entrepreneurship and SME's organisational structure. Elements of a successful business. Procedia-social and behavioral sciences, 148, 463-467.

Zaugg, R., \& Thom, N. (2002). Excellence through implicit competencies: Human resource management-organisational developmentknowledge creation. Journal of Change Management, 3(3), 199-211.

Zikmund, W. G., Babin, B. J., Carr, J. C., \& Griffin, M. (2003). Business research methods 7th ed. Thomson/South-Western

\section{ACKNOWLEDGEMENT}

I am thankful to my supervisors and other organisations which assist me to conduct this study. 


\section{AUTHORS' BIOGRAPHY}

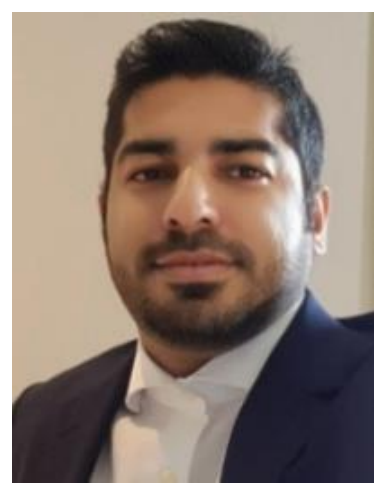

Basat Hilal Al-Balushi is a DBA student in Graduate School of Business, USM. Presently, he is a Finance Lecturer in (CAS- Nizwa). He has also seven years of banking experience in managerial role mainly engaged in large corporate and SMEs financing. The author is interested in finance, risk management and banking research areas.

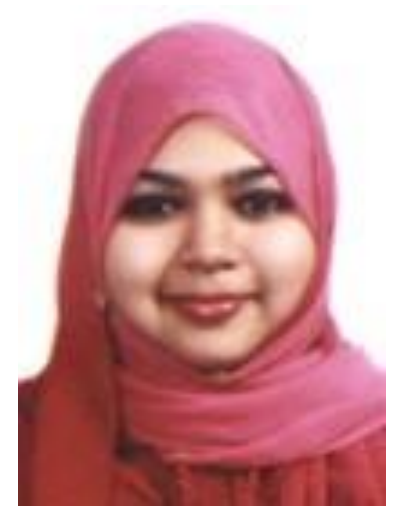

Noor Fareen Abdul Rahim is a Senior Lecturer with Graduate School of Business, Universiti Sains Malaysia (USM) since 2017. Before her career in USM, she was a banker with RHB Bank Berhad for 16 years before joining Universiti Utara Malaysia from 2015 to 2016. She has published her work in various SCOPUS and ISI journals. Her area of interest includes Organisational Behavior, Human Resource Management, Occupational Safety and Health, Internal Control System, Enterprise Risk Management, Operational Risk Management, and Technology Management. She is also involved with Executive Development Programs as a facilitator for government and private institution.

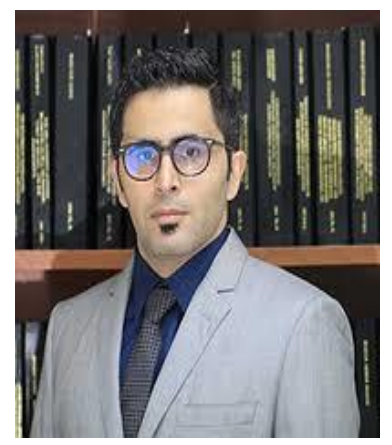

Mohammad Iranmanesh is Senior Lecturer in Edith Cowan University, Australia. He has conducted research in the fields of supply chain management, marketing, and tourism. He taught several courses, including International Marketing Fundamentals of Entrepreneurship Customer Relationship Management Research Methodology Statistics. To date, he has published in more than 30 ISI journals. 